\title{
PENGARUH MARKETING MIX DAN KUALITAS LAYANAN TERHADAP KEPUTUSAN PEMBELIAN PRODUK SIKA
}

\author{
Maria Widjajanti ${ }^{1 *}$, Bruno Hami Pahar ${ }^{2^{*}}$ \\ ${ }^{1,2}$ Program Studi Manajemen, Fakultas Ekonomi, Universitas Katolik Darma Cendika \\ Jalan Dr. Ir. H. Soekarno No.201, Surabaya \\ *Corresponding Author: mariawa9616@gmail.com ${ }^{1}$, bruno.hami@ukdc.ac.id ${ }^{2}$
}

\begin{abstract}
The purpose of this study was to determine the effect of product quality, price, promotion, service quality, and distribution on purchasing decisions of Sika products at PT Adya Mandala Persada Surabaya. The sampling method used was purposive sampling using questions in the questionnaire distributed to 125 respondents who were all consumers of PT Adya Mandala Persada Surabaya. Data processing was performed using SPSS version 20.0. The results showed that in the Validity Test all statement items were declared valid, and in the Reliability Test it was said that all variables were declared reliable. The results of the Classical Assumption Test show that all the requirements have been met to carry out the Multiple Linear Regression Test. From the results of the Multiple Linear Regression Test, the value of $Y=2.399-0.067 X 1+0.081 X 2+0.217 X 3+$ $0.234 X 4+0.697 X 5$ is obtained. The result of the Determinant Coefficient Test shows that the Adjusted $R$ Square is $54.9 \%$, meaning that all $X$ variables have a moderate contribution. The t test results get the following values: (i) variable X1 $=t_{\text {calculate }}-0.785<t_{\text {table }} 1.980$ with a significance level of $0.434>0.05$, meaning that product quality has no effect on purchasing decisions; (ii) variable X2 = $t_{\text {calculate }} 0.793<t_{\text {table }} 1.980$ with a significance level of $0.429>0.05$, which means that the price has no effect on purchasing decisions; (iii) variable X3 $=t_{\text {calculate }}$ $2,564>t_{\text {table }} 1,980$ with a significance level of $0.012<0.05$, it means that promotion has a significant effect on purchasing decisions; (iv) variable $X 4=$ $t_{\text {calculate }} 3.024>t_{\text {table }} 1.980$ with a significance level of $0.03<0.05$, it means that service quality has a significant effect on purchasing decisions; $(v)$ variable X5 = $t_{\text {calculate }} 6,063>t_{\text {table }} 1,980$ with a significance level of 0,000 $<0.05$, it means that the distribution has a significant effect on purchasing decisions. Overall it can be concluded that product quality and price have no effect on purchasing decisions while promotion, service quality, and distribution have a significant effect on purchasing decisions.
\end{abstract}

Keywords: quality, price, promotion, distribution, purchasing decisions.

\begin{abstract}
ABSTRAK
Tujuan dari penelitian ini adalah untuk mengetahui pengaruh kualitas produk, harga, promosi, kualitas pelayanan, dan distribusi terhadap keputusan pembelian
\end{abstract}


produk Sika pada PT Adya Mandala Persada Surabaya. Metode pengambilan sampel yang digunakan adalah purposive sampling dengan menggunakan pertanyaan pada kuesioner dibagikan kepada 125 responden yang merupakan seluruh konsumen dari PT Adya Mandala Persada Surabaya. Pengolahan data dilakukan dengan menggunakan SPSS versi 20.0. Hasil penelitian menunjukkan bahwa pada Uji Validitas seluruh item pernyataan dinyatakan valid, dan pada Uji Reliabilitas dikatakan seluruh variabel dinyatakan reliabel. Hasil Uji Asumsi Klasik menunjukkan semua persyaratan telah terpenuhi untuk dilakukan Uji Regresi Linier Berganda. Dari hasil Uji Regresi Linier Berganda didapatkan nilai $\mathrm{Y}=2,399-0,067 \mathrm{X} 1+0,081 \mathrm{X} 2+0,217 \mathrm{X} 3+0,234 \mathrm{X} 4+0,697 \mathrm{X} 5$. Hasil Uji Koefisien Determinan menunjukkan bahwa Adjusted $R$ Square sebesar 54,9\%, artinya semua variabel $X$ berkontribusi sedang. Hasil Uji t mendapatkan nilai: (i) variabel $\mathrm{X} 1=\mathrm{t}_{\text {hitung }}-0,785<\mathrm{t}_{\text {tabel }} 1,980$ dengan tingkat signifikansi $0,434>0,05$ artinya kualitas produk tidak berpengaruh terhadap keputusan pembelian; (ii) variabel $\mathrm{X} 2=\mathrm{t}_{\text {hitung }} 0,793<\mathrm{t}_{\text {tabel }} 1,980$ dengan tingkat signifikansi $0,429>0,05$ artinya harga tidak berpengaruh terhadap keputusan pembelian; (iii) variabel X3 = $t_{\text {hitung }} 2,564>t_{\text {tabel }} 1,980$ dengan tingkat signifikansi $0,012<0,05$ artinya promosi berpengaruh signifikan terhadap keputusan pembelian; (iv) variabel $\mathrm{X} 4=\mathrm{t}_{\text {hitung }}$ $3,024>t_{\text {tabel }} 1,980$ dengan tingkat signifikansi $0,03<0,05$ artinya kualitas pelayanan berpengaruh signifikan terhadap keputusan pembelian; (v) variabel X5 $=t_{\text {hitung }} 6,063>\mathrm{t}_{\text {tabel }} 1,980$ dengan tingkat signifikansi $0,000<0,50$ artinya distribusi berpengaruh signifikan terhadap keputusan pembelian. Secara keseluruhan dapat disimpulkan bahwa kualitas produk dan harga tidak berpengaruh terhadap keputusan pembelian sedangkan promosi, kualitas pelayanan, dan distribusi berpengaruh signifikan terhadap keputusan pembelian.

Kata kunci: kualitas, harga, promosi, distribusi, keputusan pembelian.

\section{PENDAHULUAN}

Perkembangan bisnis jasa konstruksi di Indonesia dalam beberapa tahun terakhir mengalami perkembangan yang sangat pesat. Banyaknya kegiatan pembangunan pada industri jasa konstruksi tentu membutuhkan bahan baku sebagai dasar pendukung agar suatu proyek dapat berjalan mulus serta tertata. Bahan baku pembangunan merupakan bahan yang memiliki tingkat daya tahan tinggi serta memiliki kualitas produk yang terjamin. Jika bahan yang digunakan tidak mencapai ekspektasi, maka proses pembangunan akan menjadi terhambat. Bangunan dinilai aman dan kokoh tidak hanya berdasarkan pada siapa yang memproses melainkan juga dari bahan baku pilihan yang akan digunakan.

Semakin banyak pilihan bahan baku maka semakin banyak pula potensi distribusi industri dan manufaktur yang melakukan pemasaran produk. Dalam hal ini setiap distributor harus melakukan strategi pemasaran yang berbeda-beda dari program yang diciptakan untuk mempertahankan dan meningkatkan keputusan pembelian agar dapat bersaing dengan kompetitor distributor maupun supplier lainnya. Keadaan ini tentu meningkatkan persaingan antar distributor dalam 
memperlancar dan mempermudah penyampaian barang kepada calon pembeli, terutama untuk proyek kontruksi bangunan dan industri manufaktur yang lebih membutuhkan solusi dan bahan bangunan yang berkualitas tinggi.

Salah satu bahan bangunan yang digunakan dalam berbagai proyek konstruksi adalah Sika. Perusahaan distributor resmi produk Sika di Kota Surabaya terdapat 3 (tiga) yaitu CV Multi Bangunan, CV Djaya Raya Utama, dan PT Adya Mandala Persada. PT Adya Mandala Persada beralamat di Jalan Jambi 32, Surabaya yang dipercaya oleh konsumen untuk menangani distribusi peralatan bangunan dan manufaktur untuk perusahaan besar dengan berfokus kepada pelayanan dan jaminan kualitas mutu dalam penjualan. (PT Adya Mandala Persada, 2020). Konsumen sangat selektif dalam melakukan pembelian produk, jika produk yang dihasilkan sesuai dengan manfaat maka konsumen akan melakukan keputusan pembelian dan menjadi pelanggan tetap bagi produk tersebut. Manajemen dalam perusahaan harus mampu menilai faktor apa saja yang dapat mempengaruhi perilaku konsumen dalam melakukan keputusan pembelian sehingga distributor tidak hanya sebatas memenuhi kebutuhan namun juga mengetahui keinginan maupun harapan konsumen terhadap produk tersebut.

Kualitas produk Sika meliputi daya tahan cuaca panas dan hujan, menutupi keretakan, memiliki daya rekat yang baik, kemudahan dalam cara pengaplikasian yang dapat diminati oleh konsumen. Harga yang ditawarkan oleh PT Adya Mandala Persada dapat dikatakan kompetitif dan terjangkau bagi konsumen, terutama dalam bidang pembangunan rumah dan gedung bertingkat. Banyak cara kegiatan promosi yang bertujuan untuk membujuk, mengingatkan, serta memberitahu yang dapat dilakukan antara lain dengan mengadakan program melalui media sosial, memberikan souvernir menarik dan promo cash back seperti voucher belanja maupun potongan pada pembayaran dengan pengambilan jumlah barang produk Sika yang ditentukan. PT Adya Mandala Persada juga telah memberikan pelayanan yang berkualitas kepada pelanggannya, termasuk layanan purna jual dengan cara menjalin hubungan komunikasi yang baik antara PT Adya Mandala Persada dengan toko atau pelanggan yang menjual produk Sika, membantu menjawab tantangan dan menjadi solusi dari kebutuhan bangunan. Pendistribusian dilakukan dengan cepat dan tepat sehingga produk Sika dapat ditemukan di berbagai toko bangunan di Kota Surabaya. Dalam rangka untuk mengembangkan usahanya, PT Adya Mandala Persada perlu mengetahui lebih jauh mengenai hal-hal yang mempengaruhi keputusan dari konsumen untuk membeli. Pada penelitian ini akan diteliti mengenai faktor-faktor yang mungkin mempengaruhi keputusan membeli dari konsumen. Faktor-faktor yang diteliti adalah kualitas produk, harga, promosi, kualitas pelayanan, dan distribusi.

\section{TINJAUAN PUSTAKA \\ Kualitas Produk}

Menurut Handoko (2013: 16) kualitas produk adalah suatu bentuk penilaian dari sebuah produk atau barang sesuai dengan standar ukur yang telah ditetapkan sehingga berpengaruh pada nilai produk yang semakin berkualitas. Menurut Tjiptono dalam Oentoro (2012: 130) indikator kualitas produk adalah sebagai berikut: 
a. Kinerja (Performance).

b. Kesesuaian dengan spesifikasi (conformance to specification).

c. Daya Tahan (Durability).

d. Keandalan (Reliability).

e. Estetika (Aesthethic).

\section{Harga}

Menurut Shinta (2011: 105) harga adalah bentuk suatu nilai dalam rupiah guna untuk pertukaran atau transaksi atau sejumlah uang yang harus dibayar oleh konsumen untuk memperoleh suatu barang atau jasa. Menurut Tjiptono (2015: 156) terdapat empat indikator harga, sebagai berikut:

a. Keterjangkauan harga.

b. Kesesuaian harga dengan kualitas produk.

c. Daya saing harga.

d. Kesesuaian harga dengan manfaat.

\section{Promosi}

Menurut Alma (2013: 181) promosi adalah suatu kegiatan komunikasi yang dapat memberikan penjelasan dengan tujuan untuk menyakinkan calon konsumen tentang produk barang dan jasa. Menurut Kotler dan Keller (2016: 582) pada bauran promosi terdapat 8 (delapan) alat-alat promosi, sebagai berikut:

a. Iklan (Advertising).

b. Promosi Penjualan (Sales Promotion).

c. Acara dan Pengalaman (Events and Experiences).

d. Hubungan Masyarakat dan Publisitas (Public Relation and Publicity).

e. Pemasaran Langsung (Direct Marketing and Database).

f. Pemasaran Online dan Media Sosial (Online and Social Media Marketing).

g. Pemasaran Mobile (Mobile Marketing).

h. Penjualan Personal (Personal Selling).

\section{Kualitas Pelayanan}

Menurut Tjiptono (2015: 157) kualitas pelayanan adalah ukuran seberapa bagus tingkat layanan yang diberikan dengan kemampuan sesuai ekspektasi pelanggan. Menurut Parasuraman et al. dalam Tjiptono dan Chandra (2016: 137) indikator kualitas pelayanan sebagai berikut:

a. Bukti fisik (Tangible).

b. Empati (Empathy).

c. Keandalan (Reliability).

d. Daya Tanggap (Reponsiveness).

e. Jaminan (Assurance).

\section{Distribusi}

Menurut Tjiptono (2008: 185) dalam Mandey (2013: 97) distribusi adalah kegiatan pemasaran yang berusaha untuk memperlancar dan memudahkan bentuk penyaluran proses membuat barang dan jasa setelah produksi yang pada titik puncak antara produsen ke penggunaan atau pemakaian akhir sesuai dengan yang 
diperlukan. Menurut Kotler (2007: 122) dalam Yanti et al. (2019: 76) indikator distribusi sebagai berikut:

a. Sistem Transportasi.

b. Ketersediaan Produk.

c. Waktu Penantian.

\section{Keputusan Pembelian}

Menurut Assauri (2015: 141) keputusan pembelian adalah bentuk proses pengambilan keputusan atas pembelian yang mencakup penentuan apa yang akan dibeli atau tidak melakukan pembelian dan keputusan tersebut didapat dari kegiatan sebelumnya. Menurut Kotler (2012: 479) indikator keputusan pembelian terdiri dari:
a. Pemilihan Produk.
b. Pemilihan Merek.
c. Pemilihan Saluran Pembelian.
d. Penentuan Waktu Pembelian.
e. Jumlah Pembelian.
f. Metode Pembayaran.

\section{Rerangka Berpikir}

Rerangka berpikir dari penelitian ini dapat digambarkan seperti bagan pada Gambar 1 di bawah ini.

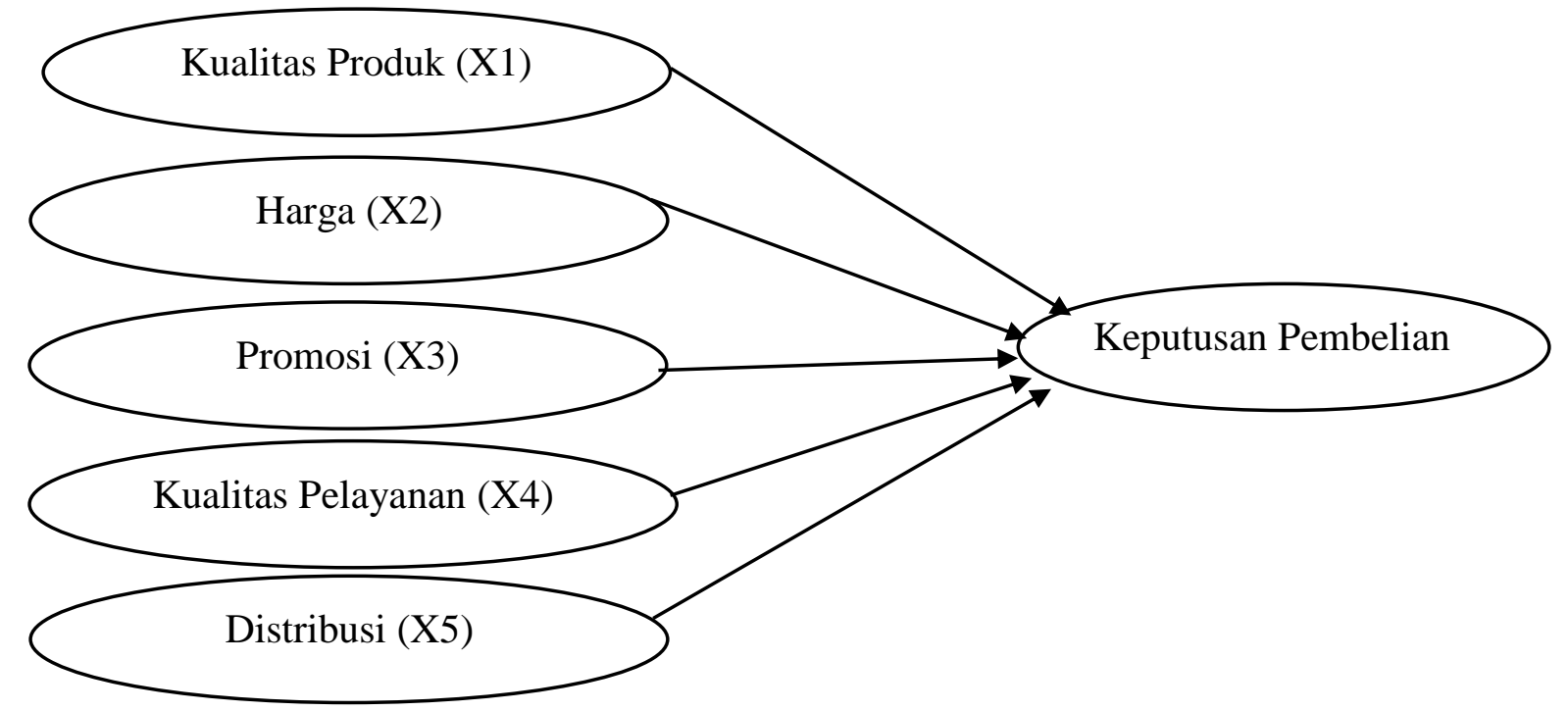

\section{Gambar 1}

Rerangka Berpikir

\section{Hipotesis}

Hipotesis yang diajukan dalam penelitian ini adalah sebagai berikut:

H1 : Kualitas produk berpengaruh signifikan terhadap keputusan pembelian produk Sika pada PT Adya Mandala Persada Surabaya. 
H2 : Harga berpengaruh signifikan terhadap keputusan pembelian produk Sika pada PT Adya Mandala Persada Surabaya.

H3 : Promosi berpengaruh signifikan terhadap keputusan pembelian produk Sika pada PT Adya Mandala Persada Surabaya.

H4 : Kualitas pelayanan berpengaruh signifikan terhadap keputusan pembelian produk Sika pada PT Adya Mandala Persada Surabaya.

H5 : Distribusi berpengaruh signifikan terhadap keputusan pembelian produk Sika pada PT Adya Mandala Persada Surabaya

\section{METODE PENELITIAN}

Pendekatan penelitian menggunakan metode kuantitatif. Data yang diteliti merupakan data primer. Pengumpulan data dilakukan menggunakan kuesioner yang diberikan kepada pelanggan dari PT Adya Mandala Persada. Skala yang dipakai pada pertanyaan yang diberikan kepada pelanggan adalah skala Likert. Hasil dari kuesioner akan diolah dengan menggunakan program SPSS versi 20.0.

\section{Definisi dan Indikator Variabel}

Variabel independen dalam penelitian ini adalah Kualitas Produk (X1), Harga (X2), Promosi (X3), Kualitas Pelayanan (X4), dan Distribusi (X5). Variabel dependen pada penelitian ini adalah Keputusan Pembelian (Y) produk Sika pada PT Adya Mandala Persada Surabaya. Kualitas produk adalah karakteristik suatu produk Sika yang di dalamnya memberikan hasil atau kinerja sesuai bahkan melebihi suatu produk Sika dari apa yang diinginkan oleh konsumen itu sendiri dengan pengambilan keputusan pada PT Adya Mandala Persada dengan indikator kualitas produk adalah kinerja, kesesuaian dengan spesifikasi, daya tahan, keandalan, dan estetika (Tjiptono dalam Oentoro, 2012: 130). Harga adalah bentuk suatu nilai dalam rupiah guna untuk pertukaran atau transaksi atau sejumlah uang yang harus dibayar oleh konsumen untuk memperoleh suatu barang produk Sika pada PT Adya Mandala Persada dengan indikator harga adalah keterjangkauan harga, kesesuaian harga dengan kualitas produk, daya saing harga, kesesuaian harga dengan manfaat (Tjiptono, 2015:156).

Promosi adalah kegiatan komunikasi manfaat dari suatu produk Sika dan menyakinkan konsumen dengan sasaran untuk membeli produk Sika pada PT Adya Mandala Persada dengan indikator promosi adalah periklanan, promosi penjualan, pemasaran langsung, pemasaran online, dan media sosial, penjualan personal (Kotler and Keller, 2016: 582). Kualitas Pelayanan adalah tingkat ukuran seberapa bagus tingkat layanan yang diberikan oleh karyawan PT Adya Mandala Persada dengan kemampuan sesuai ekspektasi pelanggan dengan indikator kualitas pelayanan adalah berwujud, empati, kehandalan, daya tanggap, jaminan (Parasuraman et al. dalam Tjiptono dan Chandra, 2016: 137). Distribusi adalah aktivitas usaha pemasaran yang dilakukan oleh PT Adya Mandala Persada dalam menjual produk Sika untuk menjamin ketersediaan produk Sika bagi konsumen atau pelanggan sasaran pada saat membutuhkan dengan indikator distribusi adalah sistem transportasi, ketersediaan produk, dan waktu penantian. Keputusan Pembelian merupakan suatu bagian dari perilaku konsumen (Kotler, 
2007: 122 dalam Yanti et al., (2019). Perilaku konsumen yang ikut terlibat dalam mengevaluasi dan memperoleh serta menggunakan produk Sika pada PT Adya Mandala Persada tersebut dengan indikator keputusan pembelian pemilihan produk, pemilihan merek, pemilihan saluran pembelian, penentuan waktu pembelian, jumlah pembelian, metode pembelian (Kotler 2012: 479).

\section{Sampel}

Metode pengambilan sampel yang digunakan dalam penelitian ini adalah non-probability sampling dengan teknik purposive sampling. Dalam penelitian ini memiliki 5 (lima) variabel independen yaitu Kualitas Produk, Harga, Promosi, Kualitas Pelayanan, dan Distribusi maka jumlah sampel dengan 25 kali 5 variabel membutuhkan sebanyak 125 responden yang melakukan pembelian produk Sika pada PT. Adya Mandala Persada Surabaya.

\section{HASIL PENELITIAN DAN PEMBAHASAN \\ Hasil Penelitian \\ Uji Validitas}

Uji Validitas dilakukan untuk mencari validitas suatu kuesioner sebagai item yang dikorelasikan skor item dengan total item-item tersebut. Uji Validitas dilakukan dengan menggunakan program SPSS versi 20.0. Hasil Uji Validitas seperti terlihat pada Tabel 1 .

Tabel 1

Hasil Uji Validitas

\begin{tabular}{|c|l|c|c|}
\hline No. & \multicolumn{1}{|c|}{ Item } & Butir & Keterangan \\
\hline 1. & X1 = Kualitas Produk & 5 & Valid \\
\hline 2. & X2 = Harga & 4 & Valid \\
\hline 3. & X3 = Promosi & 5 & Valid \\
\hline 4. & X4 = Kualitas Pelayanan & 5 & Valid \\
\hline 5. & X5 = Distribusi & 3 & Valid \\
\hline 6. & $\begin{array}{l}\text { Y= Keputusan } \\
\text { Pembelian }\end{array}$ & 5 & Valid \\
\hline
\end{tabular}

Dari Tabel 1 nampak seluruh item pernyataan pada variabel valid karena memiliki $\mathrm{r}$ hitung $>0,30$ sehingga dapat dikatakan bahwa seluruh item valid.

\section{Uji Reliabilitas}

Uji Reliabilitas dilakukan dengan menggunakan program aplikasi SPSS versi 20.0. Suatu konstruk atau variabel dikatakan reliabel jika memberikan nilai Cronbach Alpha > 0,60. Jika hasil koefisien Cronbach Alpha < tarif signifikasi $60 \%$ atau 0,60 maka kuisioner tersebut tidak reliabel. Hasil dari Uji Reliabilitas nampak seperti terlihat pada Tabel 2. 
Tabel 2

Hasil Uji Reliabilitas

\begin{tabular}{|c|l|c|c|c|}
\hline No. & \multicolumn{1}{|c|}{ Item } & Cronbach Alpha & Tarif Sig. & Keterangan \\
\hline 1. & Kualitas Produk (X1) & 0,772 & 0,60 & Reliabel \\
\hline 2. & Harga (X2) & 0,657 & 0,60 & Reliabel \\
\hline 3. & Promosi (X3) & 0,745 & 0,60 & Reliabel \\
\hline 4. & Kualitas Pelayanan (X4) & 0,833 & 0,60 & Reliabel \\
\hline 5. & Distribusi (X5) & 0,623 & 0,60 & Reliabel \\
\hline 6. & Keputusan Pembelian (Y) & 0,793 & 0,60 & Reliabel \\
\hline
\end{tabular}

\section{Uji Asumsi Klasik}

Ada 3 Uji Asumsi Klasik yang akan dilakukan, yaitu Uji Normalitas, Uji Heteroskedastisitas, dan Uji Multikolinearitas. Hasil dari 3 Uji Asumsi Klasik tersebut dapat diuraikan seperti di bawah ini:

\section{a. Uji Normalitas}

Uji normalitas bertujuan untuk menguji apakah dalam model regresi, variabel pengganggu atau residual memiliki distribusi normal atau tidak (Ghozali, 2013: 160). Hasil Uji Normalitas dengan program SPSS 20.0 seperti terlihat pada Gambar 2.

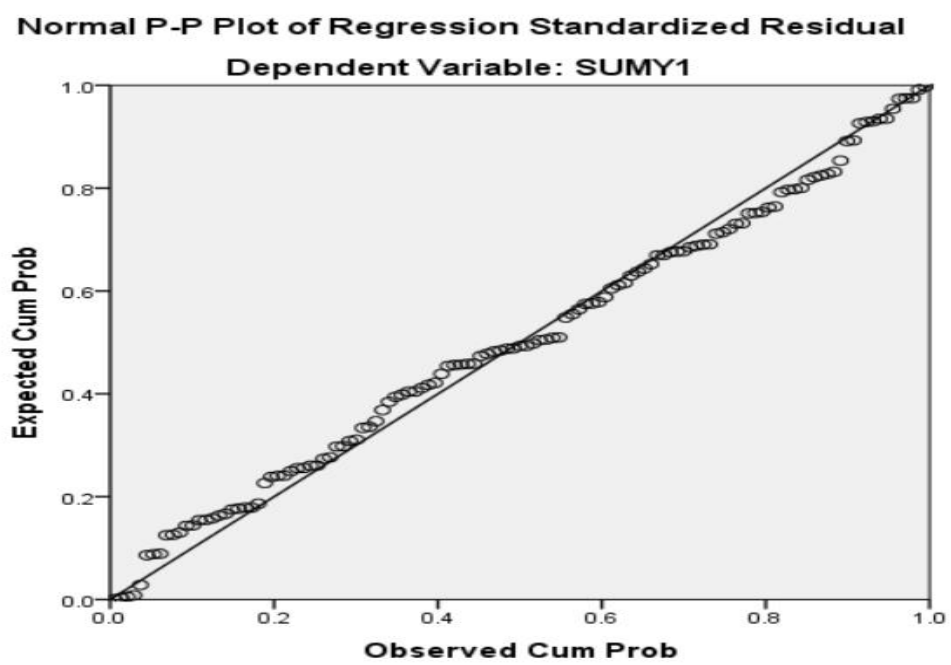

Gambar 2

Hasil Uji Normalitas

Dari Gambar 2 dapat diketahui bahwa data menyebar di sekitar garis diagonal dan mengikuti arah garis diagonal atau grafik histogramnya menunjukkan pola distribusi normal, dapat dikatakan model regresi memenuhi asumsi normalitas.

b. Uji Heteroskedastisitas

Uji heteroskedastisitas bertujuan untuk menguji apakah dalam model regresi terjadi ketidaksamaan variance dari residual satu pengamatan ke pengamatan yang lainnya. Hasil Uji Heteroskedastisitas dengan program SPSS 20.0 nampak seperti terlihat pada Gambar 3. 


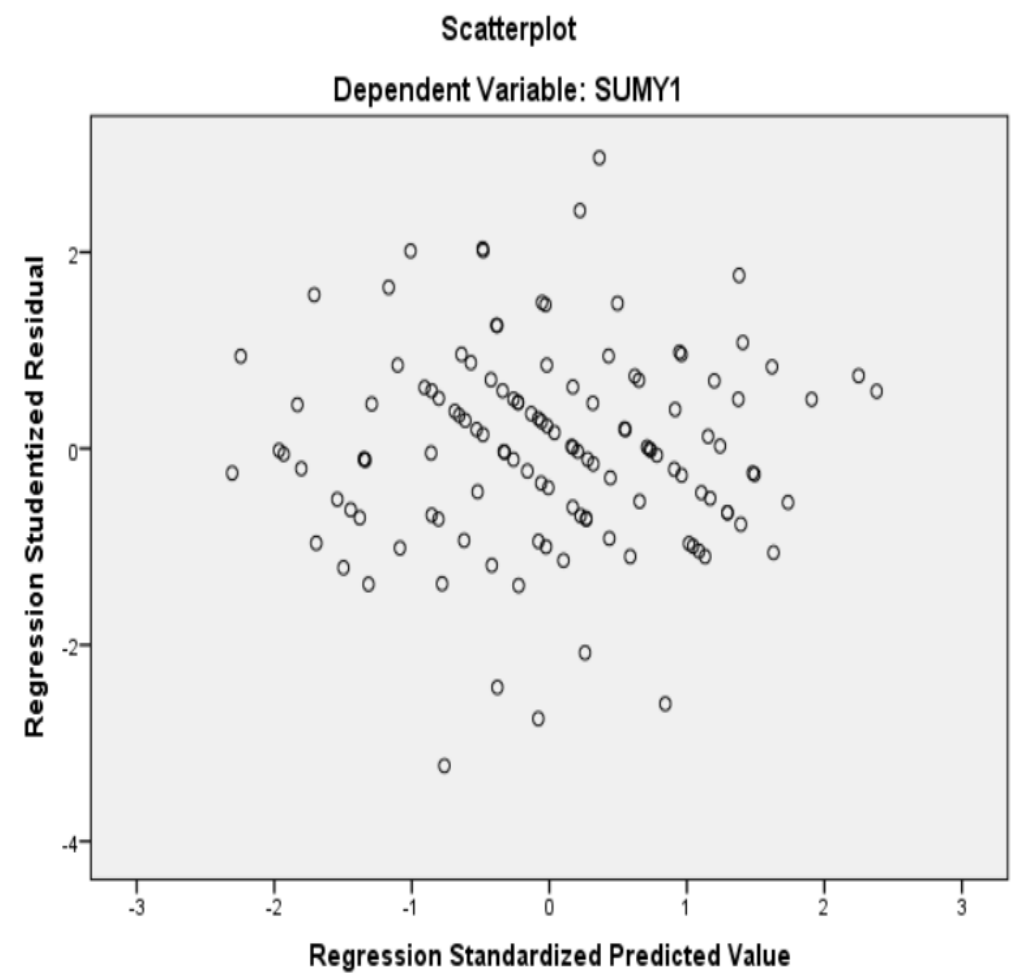

Gambar 3

Hasil Uji Heteroskedastisitas

Dari Gambar 3 dapat diketahui bahwa terdapat pola yang menggambarkan tidak ada pola yang terlihat jelas, titik-titik menyebar di atas dan di bawah angka 0 di sumbu Y, dapat dikatakan bahwa tidak terjadi heteroskedastisitas.

\section{c. Uji Multikolinearitas}

Uji Multikolinearitas bertujuan untuk menguji apakah model regresi mampu ditemukan adanya korelasi antar variabel independen (bebas). Hasil Uji Multikolinearitas dengan program SPSS 20.0 seperti terlihat pada Tabel 3.

Tabel 3

Hasil Uji Multikolinearitas

\begin{tabular}{|l|c|c|}
\hline \multirow{2}{*}{\multicolumn{1}{|c|}{ Model }} & \multicolumn{2}{c|}{ Collinearity Statistics } \\
\cline { 2 - 3 } & Tolerance & VIF \\
\hline Kualitas Produk (X1) & 0,460 & 2,172 \\
\hline Harga (X2) & 0,499 & 2,004 \\
\hline Promosi (X3) & 0,407 & 2,459 \\
\hline Kualitas Pelayanan (X4) & 0,451 & 2,218 \\
\hline Distribusi (X5) & 0,762 & 1,312 \\
\hline
\end{tabular}

Dari Tabel 3 dapat diketahui bahwa variabel Kualitas Produk (X1), Harga (X2), Promosi (X3), Kualitas Pelayanan (X4), dan Distribusi (X5) mempunyai nilai tolerance $\geq 0,1$ dan VIF $\leq 10$, sehingga dapat dinyatakan bahwa model regresi ini tidak terjadi masalah multikolinearitas dalam penelitian ini. 
Uji Regresi Linier Berganda

Hasil Uji Regresi Linier Berganda dengan program SPSS 20.0 seperti terlihat pada Tabel 4.

\section{Tabel 4}

Hasil Uji Regresi Linier Berganda

\begin{tabular}{|l|c|c|}
\hline \multirow{2}{*}{\multicolumn{1}{|c|}{ Model }} & \multicolumn{2}{|c|}{ Unstandardized Coefficients } \\
\cline { 2 - 3 } \multicolumn{1}{|c|}{ (Constant) } & B & Std. Error \\
\hline Kualitas Produk (X1) & 2,399 & 1,496 \\
\hline Harga (X2) & $-0,067$ & 0,086 \\
\hline Promosi (X3) & 0,081 & 0,102 \\
\hline Kualitas Pelayanan (X4) & 0,217 & 0,085 \\
\hline Distribusi (X5) & 0,234 & 0,077 \\
\hline
\end{tabular}

Dari hasil pada Tabel 4 dapat dibuat model persamaan regresi sebagai berikut:

$$
Y=2,399-0,067 X 1+0,081 X 2+0,217 X 3+0,234 X 4+0,697 X 5
$$

\section{Uji Koefisien Determinan}

Hasil Uji Koefisien Determinan dengan menggunakan program SPSS 20.0 dapat dilihat pada Tabel 5.

\section{Tabel 5}

\section{Hasil Uji Koefisien Determinan}

\begin{tabular}{|l|r|r|r|r|}
\hline $\begin{array}{l}\text { Mode } \\
1\end{array}$ & R & R Square & $\begin{array}{c}\text { Adjusted R } \\
\text { Square }\end{array}$ & $\begin{array}{c}\text { Std. Error of the } \\
\text { Estimate }\end{array}$ \\
\hline 1 & $.753^{\mathrm{a}}$ & .567 & .549 & 1.649 \\
\hline
\end{tabular}

Dari Tabel 5 dapat diketahui bahwa hasil dari Adjusted $R$ Square sebesar 54,9\% yang memiliki arti bahwa variabel independen yaitu Kualitas Produk (X1), Harga (X2), Promosi (X3), Kualitas Pelayanan (X4), dan Distribusi (X5) berkontribusi sedang terhadap variabel dependen yaitu Keputusan Pembelian (Y) yaitu sebesar $54,9 \%$. Sedangkan sisanya sebesar $45.1 \%$ dipengaruhi oleh variabel lain yang tidak diteliti oleh peneliti.

\section{Uji t}

Untuk melihat pengaruh masing-masing variabel bebas yaitu Kualitas Produk (X1), Harga (X2), Promosi (X3), Kualitas Pelayanan (X4), dan Distribusi (X5) terhadap variabel dependen yaitu Keputusan Pembelian (Y) dilakukan Uji t. Hasil Uji t dengan menggunakan program SPSS 20.0 nampak seperti terlihat pada Tabel 6. 


\section{Tabel 6}

Hasil Uji t

\begin{tabular}{|l|c|c|}
\hline \multicolumn{1}{|c|}{ Model } & T & Sig. \\
\hline \multicolumn{1}{|c|}{ Constant } & $\mathbf{1 , 6 0 3}$ & $\mathbf{0 , 1 1 2}$ \\
\hline Kualitas Produk (X1) & $-0,785$ & 0,434 \\
\hline Harga (X2) & 0,793 & 0,429 \\
\hline Promosi (X3) & 2,564 & 0,012 \\
\hline Kualitas Pelayanan (X4) & 3,024 & 0,003 \\
\hline Distribusi (X5) & 6,063 & 0,000 \\
\hline
\end{tabular}

\section{Pembahasan}

\section{Kualitas Produk}

Berdasarkan hasil penelitian diketahui bahwa $t_{\text {hitung }}(-0,785)<t_{\text {tabel }}(1,980)$ dan nilai signifikansi 0,434>0,05 (signifikansi yang ditentukan), maka H0 diterima dan $\mathrm{H} 1$ ditolak dapat disimpulkan bahwa Kualitas Produk (X1) tidak berpengaruh terhadap Keputusan Pembelian (Y) produk Sika pada PT Adya Mandala Persada Surabaya. Tidak berpengaruhnya kualitas produk terhadap keputusan pembelian menunjukkan bahwa produk Sika sudah dinilai oleh konsumen dari segi bahan bangunan mempunyai kualitas yang baik dengan bahan yang membuat bangunan menjadi kokoh sehingga tanpa diragukan sebagai bahan pertimbangan konsumen. Karena produk Sika dari awal sudah dipahami oleh konsumen sehingga kualitas produk Sika terhadap keputusan pembelian tidak berpengaruh, melainkan adanya perbandingan dari segi promosi, kualitas pelayanan, dan distribusi yang menjadi pilihan dalam pengambilan keputusan konsumen untuk membeli produk Sika solusi bangunan dari atap sampai lantai. Hal ini didukung dengan hasil penelitian yang telah dilakukan oleh Pandensolang dan Tawas (2015); Anastasia dan Nurendah (2014) yang menyatakan kualitas produk tidak berpengaruh signifikan terhadap keputusan pembelian.

\section{Harga}

Berdasarkan hasil penelitian diketahui bahwa thitung $(0,793)<t_{\text {tabel }}(1,980)$ dan nilai signifikansi 0,429>0,05 (signifikansi yang ditentukan), maka H0 diterima dan $\mathrm{H} 2$ ditolak dan dapat disimpulkan bahwa Harga (X2) tidak berpengaruh terhadap Keputusan Pembelian (Y) produk Sika pada PT Adya Mandala Persada Surabaya. Tidak berpengaruhnya harga terhadap keputusan pembelian menunjukkan bahwa harga produk Sika dinilai oleh konsumen dari fungsi dan manfaat dari produk Sika berimbang dengan kualitas produk yang diberikan untuk kebutuhan solusi bangunan. Karena harga produk Sika dari awal sudah dipahami oleh konsumen sehingga harga terhadap keputusan pembelian tidak berpengaruh, melainkan adanya perbandingan dari segi promosi, kualitas pelayanan, dan distribusi yang menjadi pilihan dalam pengambilan keputusan konsumen untuk membeli produk Sika solusi bangunan dari atap sampai lantai. Hal ini didukung dengan hasil penelitian yang telah dilakukan oleh Nasution et al. (2019) dan Nurhayati (2017) yang menyatakan variabel harga tidak berpengaruh signifikan terhadap keputusan pembelian. 


\section{Promosi}

Berdasarkan hasil penelitian diketahui bahwa $t_{\text {hitung }}(2,564)>t_{\text {tabel }}(1,980)$ dan nilai signifikansi 0,012 <0,05 (signifikansi yang ditentukan), maka H0 ditolak dan $\mathrm{H} 3$ diterima dan dapat disimpulkan bahwa Promosi (X3) berpengaruh signifikan terhadap Keputusan Pembelian (Y) produk Sika pada PT Adya Mandala Persada Surabaya. Berdasarkan hasil perhitungan mean dapat dikatakan bahwa responden mengetahui promosi produk Sika dari kegiatan informasi atau penjualan pribadi, di mana sales berkeliling ke setiap toko untuk melakukan penyebaran luas dari produk Sika tersebut. Selain itu responden juga mengetahui produk Sika melalui media cetak yang dibagikan oleh sales distributor dan juga setiap responden akan mendapatkan katalog untuk kejelasan lebih detail apa yang menjadi keunggulan dan fungsi masing-masing dalam kebutuhan solusi bangunan dari atap sampai lantai. Hal ini menjelaskan bahwa promosi merupakan hal penting dalam pengambilan keputusan pembelian terutama pada informasi suatu produk yang ingin dibeli. Hal ini didukung dengan hasil penelitian yang telah dilakukan oleh Nurhayati (2017) dan Fikri (2018) yang menyatakan bahwa variabel promosi berpengaruh terhadap keputusan pembelian.

\section{Kualitas Pelayanan}

Berdasarkan hasil penelitian diketahui bahwa $t_{\text {hitung }}(3,024)>t_{\text {tabel }}(1,980)$ dan nilai signifikansi $0,003<0,05$ (signifikansi yang ditentukan), maka H0 ditolak dan H4 diterima dan dapat disimpulkan bahwa Kualitas Pelayanan (X4) berpengaruh signifikan terhadap Keputusan Pembelian (Y) produk Sika pada PT Adya Mandala Persada Surabaya. Berdasarkan hasil perhitungan mean dapat dikatakan bahwa responden memilih PT Adya Mandala Persada dikarenakan kinerja karyawan yang dapat melayani dengan sangat baik, bagus dan selalu memahami apa yang diinginkan setiap konsumen pada solusi bangunan dan juga barang yang dikirim dapat diterima dengan kondisi baik. Hal ini menjelaskan bahwa dengan menciptakan pelayanan yang berkualitas akan memiliki dampak yang positif dan konsumen akan memiliki rasa kepuasan dalam dirinya setelah melakukan keputusan pembelian pada PT Adya Mandala Persada. Hal ini didukung dengan hasil penelitian yang telah dilakukan oleh Adiputra dan Khasanah (2016) dan Wulandari (2017) yang menyatakan bahwa variabel kualitas pelayanan berpengaruh terhadap keputusan pembelian.

\section{Distribusi}

Berdasarkan hasil penelitian diketahui bahwa $t_{\text {hitung }}(6,063)>t_{\text {tabel }}(1,980)$ dan nilai signifikansi $0,000<0,05$ (signifikansi yang ditentukan), maka H0 ditolak dan H5 diterima dan dapat disimpulkan bahwa Distribusi (X5) berpengaruh signifikan terhadap Keputusan Pembelian (Y) produk Sika pada PT Adya Mandala Persada Surabaya. Berdasarkan hasil perhitungan mean dapat dikatakan bahwa responden memilih PT Adya Mandala Persada dikarenakan pelayanan pengiriman barang dikirim cepat dan tepat waktu tanpa harus menunggu waktu yang lama untuk memenuhi kebutuhan konsumen. Hal ini menunjukan bahwa dengan adanya penyebaran suatu produk yang semakin luas dan tersebar, konsumen akan semakin mengenal produk tersebut kemudian 
melakukan keputusan pembelian. Hal ini didukung dengan hasil penelitian yang telah dilakukan oleh Heikal (2017); Bahtiar dan Rahardja (2017) yang menyatakan bahwa variabel distribusi berpengaruh positif terhadap keputusan pembelian.

\section{SIMPULAN}

Hasil dari penelitian dapat menyimpulkan bahwa kualitas produk dan harga tidak berpengaruh terhadap keputusan pembelian produk Sika pada PT Adya Mandala Persada Surabaya. Sedangkan promosi, kualitas pelayanan, dan distribusi berpengaruh terhadap keputusan pembelian produk Sika di PT Adya Mandal Persada.

\section{SARAN}

PT Adya Mandala Persada dapat meningkatkan kegiatan promosi dengan cara penambahan promo gift setiap bulan atau 3 bulan sekali kepada konsumen PT Adya Mandala Persada agar konsumen dapat bertambah dan meningkatkan loyalitas untuk melakukan keputusan pembelian. PT Adya Mandala Persada sebaiknya memberikan pelatihan atau training kepada karyawan 1 tahun sekali untuk penyegaran kembali materi mengenai pengembangan dalam melakukan standar pelayanan seperti komunikasi dengan cepat, tanggap, dan ramah kepada konsumen baik secara langsung (end user) maupun via-online dan toko tradisional. PT Adya Mandala Persada dapat mengatur rute pengiriman lebih tertata lagi agar barang pesanan konsumen dapat diterima dengan cepat dan dalam kondisi baik.

\section{DAFTAR PUSTAKA}

Ababil, Rega, Fauzan Muttaqien, dan Nawangsih. 2019. Analisis Kualitas Produk, Word of Mouth, dan Lokasi Terhadap Keputusan Pembelian Merek Senduro Coffee. Progress Coference, Vol. 2, pp. 572-581.

Adiputra, Yustinus Ryan dan Imroatul Khasanah. 2016. Pengaruh Kualitas Produk, Kualitas Pelayanan, Citra Merek, dan Presepsi Harga Terhadap Keputusan Pembelian Jasa Asuransi Jiwa (Studi pada AJB Bumiputera 1912 Cabang Cibinong). Diponegoro Journal Of Management, Vol. 5, No. 2, pp. 551-560.

Alma, Buchari. 2013. Manajemen Pemasaran dan Pemasaran Jasa. Bandung: Alfabeta.

Anastasia, Ulva dan Yulia Nurendah. 2014. Pengaruh Kualitas Produk dan Citra Merek Terhadap Keputusan Pembelian Konsumen. Jurnal Ilmiah Manajemen Kesatuan, Vol. 2, No. 2, pp. 181-190.

Assauri, Sofjan. 2015. Manajemen Pemasaran. Jakarta: Rajawali Persada. 
Bahtiar, Ahmad dan Edy Rahardja. 2017. Pengaruh Brand Equity, Harga, dan Distribusi Terhadap Keputusan Pembelian VAPE (Studi Pada Vape Store 5Time). Diponegoro Journal Of Management, Vol. 6, No. 4, pp. 36-45.

Deny, Septian. 2019. Menperin: Industri di RI Berkembang Pesat dalam 10 Tahun Terakhir. Diakses dari https://www.liputan6.com/bisnis/read/3980293/menper industri-diri-berkembang-pesat-dalam-10-tahun-terakhir) pada tanggal 15 September 2020 pukul 19.20 WIB.

Fikri, Miftah El. 2018. Analisis Citra Merek, Harga Distribusi, dan Promosi Terhadap Keputusan Pembelian Produk Sunlight oleh Konsumen Rumah Tangga di Kota Medan (Studi Kasus di Kecamatan Medan Polonia). Jurnal Manajemen Tools, Vol. 10, No. 2, pp. 109-124.

Ghozali, Imam. 2013. Aplikasi Analisis Multivariate dengan Program. Edisi 7. Semarang: Badan Penerbit Universitas Diponegoro.

Handoko. 2013. Manajemen. Edisi Kedua. Cetakan Ketigabelas. Yogyakarta: BPFE.

Heikal, M.. 2017. Pengaruh Citra Merek dan Distribusi Terhadap Keputusan Pembelian pada PT Harian Waspada Medan. Journal of Economic Management and Business, Vol. 18, No. 1, pp. 51-65.

Kotler. 2012. Manajemen Pemasaran. Jakarta: PT Indeks Kelompok Gramedia.

Kotler, Philip and Kevin Lane Keller. 2016. Marketing Management, $15^{\text {th }}$ Edition. Pearson Education Limited.

Mandey, Jilly Bernadette. 2013. Promosi, Distribusi, Harga Pengaruhnya Terhadap Keputusan Pembelian Rokok Surya Promild. Jurnal EMBA, Vol. 1, No 4, pp. 95-104.

Nasution, Asrizal Efendy, Linzzy Pratama Putri, dan Muhammad Taufik Lesmana. 2019. Analisis Pengaruh Harga, Promosi, Kepercayaan, dan Karakteristik Konsumen Terhadap Keputusan Pembelian Konsumen Pada 212 Mart di Kota Medan. Proseding Seminar Nasional Kewirausahaan, Vol. 1, No. 1, pp. 194-199.

Nurhayati, Siti. 2017. Pengaruh Citra Merek, Harga, dan Promosi Terhadap Keputusan Pembelian Handphone Samsung di Yogyakarta. Jurnal Bisnis, Manajamen, dan Akuntansi, Vol. 4, No. 2, pp. 60-69.

Oentoro, Deliyanti. 2012. Manajemen Pemasaran Modern. Cetakan Pertama. Yogyakarta: Laksbang Pressindo.

Pandesolang, Josiel Driand dan Hendra Novi Tawas. 2015. Pengaruh Diferensiasi, Kualitas Produk, dan Ekuitas Merek Terhadap Keputusan Pembelian CocaCola pada PT Bangun Wenang Beverges Company di Manado. Jurnal Riset Ekonomi, Manajemen, Bisnis, dan Akuntansi, Vol. 3, No. 3, pp. 1113-1124. 
PT Adya Mandala Persada, 2020. Tentang Kami. Diakses dari http://www.pt. amp.co.id/page/view/4_tentang_kami pada tanggal 15 September 2020 pukul 19.20 WIB.

Shinta, Agustina. 2011. Manajemen Pemasaran. Malang: UB Press.

Supriyadi, Yuntawati Fristin dan Ginanjar Indra K. N.. 2016. Pengaruh Kualitas Produk dan Brand Image Terhadap Keputusan Pembelian. Jurnal Bisnis dan Manajemen, Vol. 3, No. 1, pp. 135-144.

Tjiptono, Fandy. 2015. Strategi Pemasaran. Yogyakarta: Penerbit Andi.

Tjiptono, Fandy dan Gregorius Chandra. 2016. Service, Quality dan Satisfaction. Yogyakarta: Penerbit Andi.

Wulandari, Tresna. 2017. Pengaruh Citra Merek Suzuki dan Kualitas Pelayanan Terhadap Keputusan Pembelian pada Dealer XYZ. Value Journal of Management and Business, Vol. 2, No. 1, pp. 250-259.

Yanti, F. Asih, F. Abbas, dan M. Syauki. 2019. Pengaruh Kualitas Produk dan Distribusi Terhadap Penjualan Teh Poci. Jurnal Humaniora, Vol. 3, No. 1, pp. 72-84. 